\title{
Time Series Study of Rhino Habitat and its Impact on Rhino Population in Gorumara National Park through Remote Sensing Technology
}

\author{
Sumita Ghatak*1, P.T Bhutia ${ }^{2}$, Abhijit Mitra ${ }^{3}$, Atanu Kumar Raha ${ }^{4}$ \\ ${ }^{1,2}$ Forest Department, West Bengal, India \\ ${ }^{3,4}$ Techno India University, Salt Lake, West Bengal, India
}

\begin{abstract}
Gorumara National Park located within the flood plains of Jaldhaka and Murty river in the Dooars area of Northern West Bengal has a mosaic of natural vegetation consisting of tall grasslands, woodlands, tropical semi-evergreen forests and tropical moist deciduous forests, part of which get inundated in recurring floods. The Greater Indian One Horned Rhinoceros which is the flagship specie of this National Park has positively responded to the regular Wild Life Habitat Management regime introduced since 1995 showing trends of steady increase in its population as the habitat manipulation resulted in the increase of the Rhino habitat. This review tries to establish the Rhino population dynamics vis a vis increase in Rhino habitat using Remote sensing technology over the years since the area comes under purview of Protected Area network management.
\end{abstract}

Keywords- Gorumara National Park (GNP), Greater Indian One Horned Rhinoceros, Rhino Habitat, Habitat Management, Rhino Population, Remote Sensing Technology.

\section{INTRODUCTION}

Greater Indian one-horned Rhinoceros (Rhinoceros uniforms), a large herbivore of Himalayan foot hill flood plains, is adapted to a mosaic of tall grasslands and riverine forests where water and some green growth remains available throughout the year. The species has faced major setback from habitat loss and heavy poaching. As a result, it became confined to only certain Protected Areas (PAs) of Assam, West Bengal in India and Nepal besides a small reintroduced population in Dudhwa National Park, Uttar Pradesh in India. ${ }^{[4,7]}$ Long term conservation of this species requires much more intensive management supported by detailed ecological information on the species and remnant habitat patches for which Remote Sensing Technology can provide invaluable service. In West
Bengal habitat fragmentation has resulted in the confinement of the species in two isolated areas of North Bengal which have been declared as Protected Areas, namely Jaldapara National Park and Gorumara National Park where the Greater Indian one horned Rhinoceros is treated as the flagship sps.

The forests of Gorumara National Park were earlier part of the Jalpaiguri Forest Division comprising an area of 2129 Acre being declared as Gorumara Game Sanctuary vide Govt. Notification No. 5181-For, dt: 02.08.49. Subsequently, notification was issued under the Wildlife (Protection) Act, 1972, vide No. 5400-For, dt: 24th June, 1976, comprising a total area of $8.62 \mathrm{Sq} . \mathrm{km}$. of Jalpaiguri Division declaring the area as Gorumara Wildlife Sanctuary. It was finally notified as a National Park, under Wild Life (Protection) Act, 1972, in the year $1998^{[4,5,17]}$

As part of Biodiversity Conservation measures under the National Forest Policy of 1988, initial notification for constitution of Gorumara National Park was issued by curbing out $79 \mathrm{sq} \mathrm{km}$ of forest areas of Jalpaiguri Forest Division and its management was handed over to a newly constituted Wildlife Division under the Wildlife wing in $1995^{[5,17]}$.

Gorumara National Park had been further extended by taking over possession of $474.58 \mathrm{Ha}$ adjoining non forest land as Compensatory Afforestaion Scheme against diversion of forest land for implementation of Teesta Low Dam Project Stage III and IV in Darjeeling District during 2005-2009.

Prior to 1994, major management of these forest areas was to maximise timber protection followed by plantation of monoculture commercial species, mostly Teak and Jarul. However, with the advent of changes in the management of the forests under the National Park, objectives of management were prioritized with conservation of Wildlife and biodiversity getting 
precedence over timber harvesting, and all commercial operations came to a stop.

The first Management Plan of Gorumara National Park was prepared and approved by Ministry of Environment and Forests, Govt. of India in1997-98 for habitat management of the National Park.

However, since the area came under Wild Life Wing in 1995 different management practices are being adapted by the Park Authority for improving the habitat of its flagship species Greater Indian One horned Rhinoceros and other wild animals.

Rhino is adapted to feed mainly on fibrous food like grasses along with a wide variety of plants. Other components of diet include fruit, leaves, branches of shrubs, trees as well as aquatic vegetation. Among the grasses, Saccharum narenga, Saccharum longisetosum, Themeda arundinarea, Axonopus compressus, Phragmites karka, Arundo donax are important. Occasional flooding of the riverine areas lead to colonization by grasses, shrubs and pioneer tree species which also ensures the supply of diverse food items preferred by Rhino. Such diverse food along with abundant water, aquatic vegetation and woodland/ riverine forest are crucial requirement for management of a growing Rhino population ${ }^{[3]}$.

This review deals with study of the Rhino population dynamics vis a vis increase in Rhino habitat using Remote sensing technology over the years in Gorumara National Park in West Bengal, India since the area comes under purview of Protected Area network.

\section{MATERIALS AND METHODS}

\section{Description of site:}

Gorumara N.P is situated in the Dooars region of Jalpaiguri district in the state of West Bengal between latitude $26^{\circ} 47^{\prime} 12.5^{\prime \prime}$ North to $26^{\circ} 43^{\prime} 25.6^{\prime \prime}$ North and longitude $088^{0} 52^{\prime} 04.2^{\prime \prime}$ East to $088^{\circ} 47^{\prime} 07.3^{\prime \prime}$ East in Jalpaiguri District in West Bengal in India.

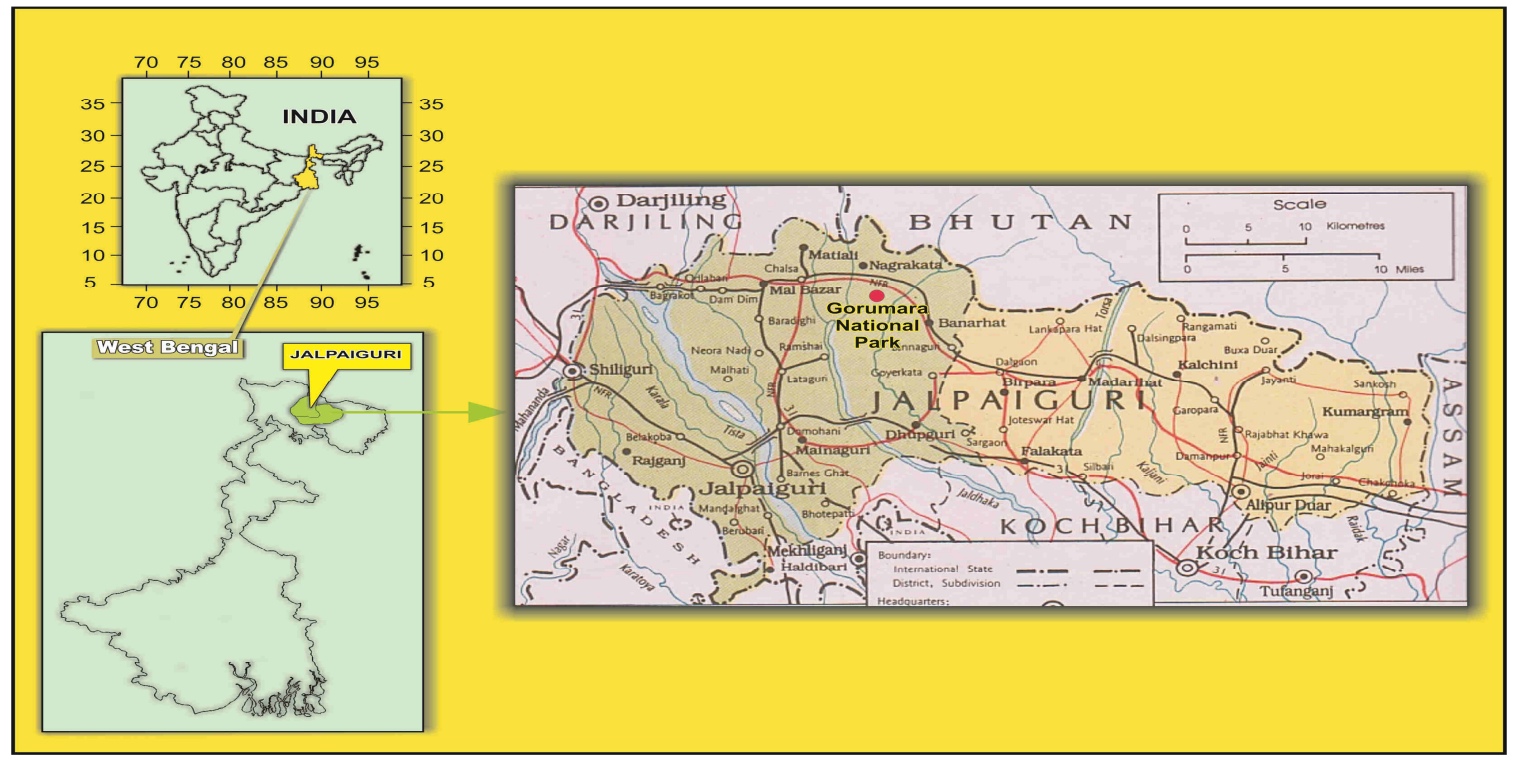

Location Map of Gorumara National Park

Gorumara National Park, besides being the home of the home of the endangered Greater Indian one horned Rhinoceros (Rhinoceros unicornis) also harbours other major wild animals like elephants, gaurs, leopards, different types of deer and other wildlife. There are records of the past that indicates one more species of rhino. viz. Rhinoceros sondaicus, i,e Javan Rhino used to exist in North Bengal, but it became extinct much earlier. The last recorded sighting of the species was in the forests of Chilapata in $1900 .{ }^{[1]}$ Besides Gorumara area (Jaldhaka -Murty-Diana flood plains) Greater Indian one horned Rhinoceros now exists only in Jaldapara National Park (Torsa river flood plains) in West Bengal. There are records that previously this species was also distributed in Sankosh - Rydak flood plains. Rhinos were reported to be plentiful in North Bengal till towards the end of the 19th Century. According to the estimates of the Fawcus Committee there were about 200 rhinos in the Torsa region and a dozen so in the other pockets in North Bengal in 1920. The hunting records of Maharaja of Cooch Behar indicate that about 201 rhinos were either killed or injured in North Bengal between 1871 and 1905 and the death figure for the period 1890-1905 was $42^{[4]}$.

By the middle of twentieth century, the Greater Indian one-horned rhinoceros became extinct from most of the earlier natural habitats of Dooars/ Himalayan foothills of North Bengal, except in two isolated pockets of 
erstwhile Jaldapara Wild Life Sanctuary (216 sq km) and Gorumara national Park (79 sq km). The population of Rhino in Jaldapara and Gorumara, as per 1994 census were a meagre 33 and 12 respectively.

This National Park has 158 no. of tree species, 35 no. of herb species, 77 no. of shrub species, 32 no. of grass species, 15 no. of climber species and 50 no. of orchid species (identified till date).

It also harbours 48 species of mammals, more than 200 species of birds, 22 species of reptiles, 7 species of turtles, 50 species of fishes, more than 300 species of butterflies ((identified till date)and other macro and micro fauna ${ }^{[5,17]}$.

This small but important National Park lies in Biogeographic zone 7B (Lower Gangetic Plain) as recognized by WII, Dehradun (Rodgers and Panwar, 1988). ${ }^{[5,17]}$

The forests of Gorumara belong to North Indian Moist Tropical Forest as per Champion and Seth's classification. However, on basis of crop composition four major forest types namely- Riverine forests (Northern dry deciduous Seral Sal Khair Sissoo Association), Sal forests (Eastern Bhabar Sal and Easter Terai Sal), Wet mixed forests (Sub-Himalayan Secondary Wet Mixed Forests) and Savannah forests (Sal Savannah) have been identified. (SourceManagement Plan of Gorumara National Park for the period 2007-08 to 2017-18 and other publications by Wild Life Division-II, West Bengal Forest Dept.

At the time of constitution of national Park in 1994, much of the forests were of plantation origin, with patches of monoculture/ teak dominating the plantations. The natural forests comprises species like Khair (Acacia catechu), Sissoo (Dalbergia latifolia), Simul (Bombax ceiba), Pitali (Trewia nudiflora), Kainjal (Bischofia javanica), Sal and its other associates like Bahera (Terminalia belerica), Chilauni (Schima wallichii), Kawla (Machilus villosa), Champ (Michelia champaca), Chikrasi (Chukrasia tabularis), Jarul (Lagerostroemia speciosa), Sidha (Lagerostroemia parviflora), Lali (Amoora wallichii), Kawla (Machilus villosa), Lali (Amoora wallichii), Jamun (Syzygium sp), Lasunae (Dysoxylum binectarifenum), Katus (Castanopsis sp), Siris (Albizia $\mathrm{sp}$ ), Sidha (Lagerostroemia parviflora) The extent of grassland, which forms the core of a rhino habitat, was only around $6.00 \mathrm{sq} \mathrm{km}$. Two perennial rivers Murti and Jaldhaka flows through/ along the periphery of the National Park, thus providing sufficient water to the habitat and also leaving scope of additional foraging ground for the Rhino ${ }^{[5,17]}$.

\section{OBJECTIVE OF THE STUDY}

1) To prepare vegetation maps of Gorumara National Park using Remote Sensing technology, for delineation of habitat niche of Rhino

2) To identify the nature of spatial and temporal changes of the habitat of Rhino over the past 15 years vis-a-vis growth characteristics of Rhino population

3) Delineate Habitat manipulation zones to improve fodder availability for the growing rhino population.

\section{METHODOLOGY}

Gorumara National Park is situated in the flood plains of Murti-Jaldhaka river system which originate from the foothills of the Himalayas. Occasional flooding of the floodplains and the forest areas along both banks of the rivers keep on altering the extent of grassland which are the prime habitats of rhino. In addition, habitat development activities like canopy opening of plantation forests, controlled burning of grassland, removal of overwood from grassland and plantation of grasses also introduces dynamic changes in the extent of foraging areas of rhino. Considering the difficulties encountered while making manual assessment of the grassland and forest composition, on frequent basis, Remote sensing technology is found to be the most suitable tool for monitoring the habitat changes on real time basis ${ }^{[2,6,9-11,12,13,15,18,19]}$.

Satellite imageries of North Bengal forest, containing Gorumara National Park and adjoining forest areas of Jalpaiguri Forest Divisions were requisitioned from NRSC, Hyderabad. Radiometrically and Geometrically corrected digital data from IRS 1C/ 1D satellites for the period 1998, 2002 and from IRS P6 for the period 2006, 2010 and 2013 were procured. The data were in 4 bands, namely Band 1,2,3,4 corresponding to green, red, IR and Thermal IR Bands.

The digital data were registered with each other and subsets coinciding with legal boundary of Gorumara National Park were extracted from the corresponding sub-scenes. ERDAS Imagery version 8.2 was used for satellite data handling/ processing.

The satellite data pertaining to each period of 1998 , 2002, 2006, 2010, 2013 and 2014 were then classified using unsupervized classification model.

The classified data were then grouped into the broad classes of Dense forest, Open forest/ grassland, Water body/ rivers/ wetland and sandy/ river beds. The last three classes are the known and preferred habitats of Rhino. Based on these broad classifications, data bases were generated to compare the changes in possible 
habitat zones of Greater India One Horned rhinoceros in the National Park over a period of 15 years.

Available old records, past census data and working/ Management Plans of Gorumara National Park were also scanned to prepare the chart of changes in Rhino population over last 40 years.

\section{RESULTS AND DISCUSSIONS}

When the population figures were plotted against time, the best fitted graph was an exponential one, showing the exponential growth of Rhino population with time. During the year 1974, the population was estimated to be 7 only and even over a period of almost 20 years, the population was estimated to be only 15 in 1993 indicating that the growth rate was 0.027 .

The Population started growing slowly from the period 1994-1997 which incidentally also coincides with the canopy-opening and grassland development operations as part of habitat manipulation practices ${ }^{[14]}$.

Time-series analysis of satellite data shows that the preferred Rhino Habitat zone was hardly $20 \%$ of the area of the National Park in the year 1998 which has increased to around $25 \%$ of the National Park over a period of 15 years. During the year 1998, the population had risen to 35 and in the last census in 2015 it was estimated to be 51 showing an increase in the growth rate to 0.04 . Graphical representation shows a very good correlation between the year and Rhino habitat which are the results of proactive management of the grassland/ canopy opening and wetland preservation in the National Park.

There is an increase of grassland/ wetland of about 4.75 Sq KM adjoining Gorumara National Park which is the result of pro-active management of the congested plantation patches adjoining the grassland, as well as soil-moisture conservation and plantation measures in the limited grassland habitat of the National Park, since 1993-94.

It, thus, is evident that the increase in Rhino population which remained almost stagnant till 1993, was directly linked to increase in foraging area and compatible habitat of Rhino.

Table-1 : Census Year and Rhino Population in GNP

\begin{tabular}{|c|c|}
\hline Census Year & $\begin{array}{c}\text { Rhino } \\
\text { population }\end{array}$ \\
\hline 1974 & 6 \\
\hline 1978 & 8 \\
\hline 1986 & 8 \\
\hline 1989 & 12 \\
\hline 1993 & 12 \\
\hline 1996 & 14 \\
\hline 1997 & 14 \\
\hline
\end{tabular}

\begin{tabular}{|l|l|}
\hline 1999 & 19 \\
\hline 2000 & 19 \\
\hline 2001 & 22 \\
\hline 2004 & 25 \\
\hline 2006 & 27 \\
\hline 2008 & 31 \\
\hline 2010 & 35 \\
\hline 2012 & 43 \\
\hline 2014 & 50 \\
\hline 2015 & 51 \\
\hline
\end{tabular}

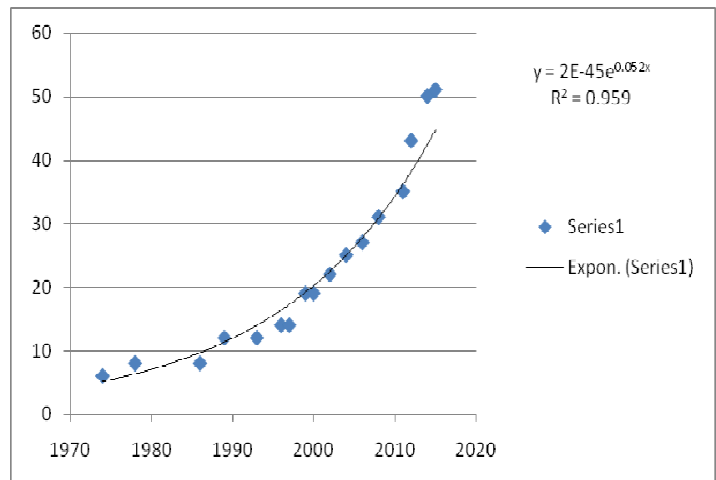

Fig 1: Rhino population (y axis) vs Year (x axis) in GNP

Table 2: Change in Extent of Rhino habitat over the years in GNP

\begin{tabular}{|c|c|c|c|}
\hline $\begin{array}{c}\text { Year of } \\
\text { mapping }\end{array}$ & $\begin{array}{c}\text { Grassland+wetland } \\
\text { (Rhino Habitat) } \\
(\text { Sq Km) }\end{array}$ & $\begin{array}{c}\text { Grassland } \\
(\text { Sq Km })\end{array}$ & $\begin{array}{c}\text { Wetland } \\
(\mathrm{Sq} \\
\mathrm{Km})\end{array}$ \\
\hline 1998 & 16.62 & 6.37 & 10.25 \\
\hline 2002 & 18.87 & 8.41 & 10.46 \\
\hline 2006 & 24.64 & 12.49 & 12.15 \\
\hline 2010 & 24.46 & 13.45 & 11.01 \\
\hline 2013 & 25.85 & 11.91 & 13.94 \\
\hline
\end{tabular}

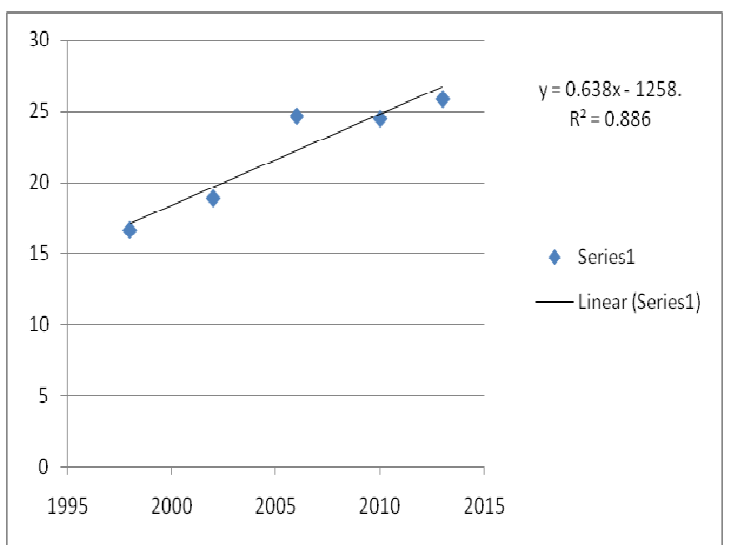

Fig 2: Extent of Rhino habitat in $\mathrm{Sq} \mathrm{Km}$ ( $Y$ axis) vs Year (X axis) in GNP 


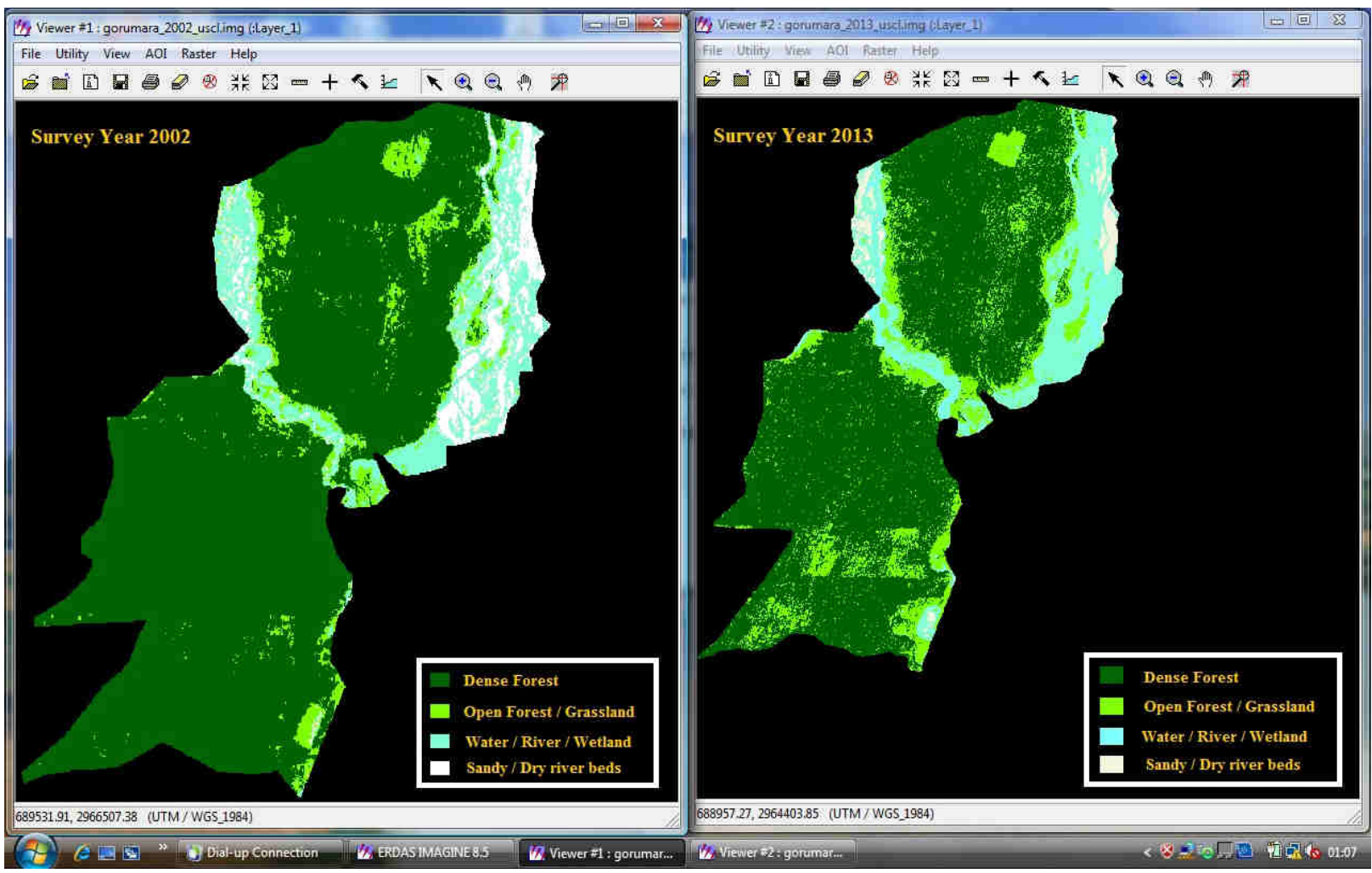

Fig 3: Comparative classified satellite imageries for 2002 and 2013

\section{CONCLUSION}

Gorumara National Park is one of the two forest areas of the State naturally inhabited by Rhino. The two rivers Jaldhaka and Murti, flowing through the National Park and its adjoining forest areas, are extremely crucial towards maintenance and development of the habitat. For management of the Rhino population, canopy opening operations will be more productive in the buffer areas of the wetland/ water bodies instead of their creation in dense forest areas away from the low-lying areas. There is also a need to revert to and follow prescriptions of Grassland Working Circles which used to be practised in the flood plains to arrest succession beyond the stage of grasses so as to encourage preservation and maintenance of the grasslands that form an important part of the Rhino habitat ${ }^{[8]}$. No study is available on carrying capacity of grassland which is shared by both Rhino as well as Gaur which is the case of Gorumara National Park. Hence it is difficult to predict the present carrying capacity of Gorumara National Park with reference to Rhino population. However, periodic monitoring of the habitat using Remote Sensing Technology will be an extremely useful tool for the Park Manager to plan and organize the habitat manipulation activities to facilitate sustenance and growth of Rhino till it attains peak and stability in Gorumara National Park.

\section{REFERENCES}

[1] Annual Reports on game preservation or Wildlife Preservation in Bengal; Govt. Of Bengal (or West Bengal), Directorate of Forests for the year 193637 (14.2.).

[2] Atanu Kumar Raha, Amitav V. Mishra, Susmita Das, Sufia Zaman, Sumita Ghatak, Sumana Bhattacharjee, Srilekha Raha, Abhijit Mitra (2014). Time Series Analysis of Forest and Tree Cover of West Bengal from 1988 to 2010, using RS/GIS, for Monitoring Afforestation Programmes. The Journal of Ecology. Photon 108 (2014) 255-265

[3] Bhattacharya, A. and Pal, B. C. (1982). Daily Activity Cycle of Greater Indian one horned rhinoceros at Gorumara and Jaldapara wildlife sanctuary in West Bengal. All India Symposium on Wildlife Biology 12: 1-5.

[4] Bist. S.S. "Population History of Greater Indian Rhinoceros in North Bengal and major factors influencing

[5] The same" Zoo's Print March April 1994 pp 7489 (First Draft of the PHVA Workshop for Indian Rhino, Jaldapara, WB $6^{\text {th }}-10^{\text {th }}$ Dec, 1993.

[6] Das Tapas and Debnath Bimal. Management Plan of Gorumara National Park (2007 to 2017) 
[7] Dubeni. $\mathrm{N}$ and Debba, P, "Classification of remote sensing images," in Proceedings of the South African Statistical Association Conference, Pretoria, South Africa, October 2008

[8] Day R. and Singh R.L.(2000), Management Plan of Dudhwa National Park for the period 2000-01 to 2010-11.

[9] Ghatak. S, Mitra. A, Pramanik. P, Raha. A. K, Stored Carbon in the Grassland Habitat of Gorumara National Park, West Bengal, India, IARJSET, Vol-2, Issue, 10, Oct, 2015.pp 110113.

[10] Kushwaha. S. P. S, "Forest-type mapping and change detection from satellite imagery," ISPRS Journal of Photogrammetry and Remote Sensing, vol. 45, no. 3, pp. 175-181, 1990.

[11] Kushwaha S. P. S, Roy . P. S , Azeem. A, Boruah. P, and Lahan .P, "Land area change and rhino habitat suitability analysis in Kaziranga National Park, Assam," Tigerpaper, vol. 27, no. 2, pp. 9-16, 2000.

[12] Kushwaha S.P.S., and Madhav Unni N.V. (1986). Application of remote sensing techniques in forest cover monitoring and habitat evaluation-A case study at Kaziranga National Park, Assam. (Eds. Kamat D.S. and Panwar H.S.). A seminarcum-workshop on Habitat Evaluation Using Remote Sensing Techniques. Dehradun. Pp. 265

[13] Porwal M.C, Roy P. S. And Chellamuthu V. "Wildlife habitat analysis for 'sambar' (Cervus unicolor) in Kanha National Park using remote sensing," International Journal of RemoteSensing, vol. 17, no. 14, pp. 2683-2697, 1996.

[14] Raha A K (Principal Investigator) et al (1993), Forest Cover Mapping of West Bengal State through Digital Image Processing of Indian Remote Sensing Satellite data - procedural manual and inventory.

[15] Raha A K (Principal Investigator) et al (1994), Forest Change Detection Studies on nine districts of West Bengal through Digital Image Processing of Indian Remote Sensing Satellite data between 1988 -1991 - procedural manual and inventory.

[16] Raha A.K.(ed) (1996): Wild Life Conservation in West Bengal- A Decade at a glance, Wild Life Wing, Forest Department, Government of West Bengal, Kolkata.

[17]Raha A K, Sudhakar S, Prithviraj M (1997) Forest Change Detection Studies and Wetland Mapping through Digital Image Processing of Indian Remote Sensing Satellite Data.
[18]Raha A K (Ed) (1998), Management Plan of Gorumara National Park

[19] Sudhakar S, Krishnan N, Ramana I V, Das P K, Raha A K (1992), Forest Cover using IRS-IA LISS II data. Asian Pacific Remote Sensing Journal. Vol 4.(2).pp 25-30.

[20] Sudhakar S, Sengupta S, Venkata Ramana I, Raha A K, Bardhan Roy B K (1996) - Forest Cover Mapping in West Bengal etc. Int. Journal of Remote Sensing. Vol 17, No. 1, pp 29-42. 